\title{
The effects of firm-initiated clawback provisions on earnings quality and auditor behavior
}

\section{A R T I C L E I N F O}

JEL classification:

G30

L50

M41

Keywords:

Clawbacks

Accounting restatements

The Dodd-Frank Act

Audit risk

Audit fees

\begin{abstract}
A B S T R A C T
While firm-initiated compensation recovery (or clawback) provisions are gaining popularity and the recently enacted Dodd-Frank Act seeks to make the clawback of erroneously awarded compensation mandatory for all listed companies, little is known about their effectiveness. We find that the incidence of accounting restatements declines after firms initiate such provisions. In addition, we show that investors and auditors view such provisions as associated with increased accounting quality and lower audit risk. Specifically, we find that firms' earnings response coefficients increase after the adoption of clawback provisions. Further, for firms that adopt clawbacks, auditors are less likely to report material internal control weaknesses, charge lower audit fees, and issue audit reports with a shorter lag.
\end{abstract}

\section{Introduction}

Compensation recovery provisions (commonly known as "clawbacks"), which allow firms to recoup compensation from corporate executives involved in accounting improprieties, were first introduced by Section 304 of the Sarbanes-Oxley Act (hereafter, SOX 304) in 2002. SOX 304 authorizes the Securities and Exchange Commission (SEC) to enforce the recovery of bonuses paid to CEOs and CFOs of public companies when the company restates its financial statements due to material noncompliance with any financial reporting requirement as a result of misconduct. However, due to the ambiguities in SOX 304 and the SEC's limited resources, SOX 304 has been successfully enforced in only a few cases (Salehi and Marino, 2008; Fried and Shilon, 2011; Morgenson, 2011). To facilitate the enforcement of clawbacks, the 2010 Dodd-Frank Wall Street Reform and Consumer Protection Act also includes a section (Section 954) on the recovery of erroneously awarded compensation (hereafter, DFA 954). DFA 954 improves upon SOX 304 in two important respects. First, it designates a firm's board of directors, rather than the SEC, as the enforcer of clawbacks. Second, it does not require misconduct as a prerequisite for clawbacks.

Since DFA 954 will not be implemented until the first half of 2012, it is not yet possible to empirically determine the extent to which mandatory clawbacks enforced by the board enhance financial reporting integrity. ${ }^{1}$ The usefulness of the mandatory clawbacks, however, can be inferred from the clawbacks that are adopted voluntarily. Voluntary clawbacks have become increasingly popular among listed companies in recent years. According to a survey reported by Corporate Library, 194 companies in the S\&P 500 index (about 39\%) had adopted clawback provisions as of early 2010. Similar to DFA 954, voluntary clawbacks designate a firm's board as the enforcer of the clawbacks. However, unlike DFA 954, voluntary clawbacks usually require misconduct as a prerequisite for enforcement (Fried and Shilon, 2011). Voluntary clawbacks are therefore stronger than SOX 304 but weaker than DFA 954. If firm-initiated clawbacks are found to improve financial reporting quality, DFA 954 is also likely to be beneficial. In this study, we examine the impact of firm-initiated clawbacks on the likelihood of financial misstatements and on earnings credibility as perceived by investors. We also examine how external auditors respond to the initiation of clawback provisions.

We are grateful for helpful comments from an anonymous referee, Donal Byard, John Core, Mark DeFond, Diane Denis (the discussant), S.P. Kothari (the editor), Clive Lennox, Chul Park, participants at the 2011 Journal of Accounting and Economics Conference at the Wharton School of University of Pennsylvania, and workshop participants at Baruch College-CUNY, Cheung Kong Graduate School of Business, Hong Kong University of Science and Technology, National Cheng-Chi University, and The University of Hong Kong. All errors are our own. shtml).

${ }^{1}$ The SEC plans to adopt the rules to implement DFA 954 in the first half of 2012 (see http://www.sec.gov/spotlight/dodd-frank/dfactivity-upcoming. 
More specifically, we first examine whether the voluntary initiation of clawbacks reduces the incidence of financial restatements, a relation that is not obvious ex ante. On the one hand, the "causal" argument predicts that firm-initiated clawbacks change managerial behavior. The reason is that clawback provisions impose additional monetary penalty on managers who engage in earnings manipulation. As argued by Desai et al. (2006), if managers understand that their fraudulent behavior will be penalized ex post through the loss of income, job, and/or reputation, they are likely to have fewer incentives to engage in earnings manipulation ex ante. On the other hand, clawback initiation may not reduce financial misstatements because, as mentioned earlier, voluntary clawbacks often tie compensation recovery to the existence of misconduct. As a result, there is uncertainty about whether a firm's board can win a lawsuit against an executive to recover compensation and hence about the effectiveness of firm-initiated clawbacks (e.g., Dvorak and $\mathrm{Ng}$, 2006; Weiss, 2009; Lublin, 2010). In addition, it is possible that voluntary clawbacks may simply be a signal of financial integrity. The "signaling" argument (e.g., Spence, 1973) predicts that firms with high reporting quality might use clawback provisions to provide investors information about their reporting quality. Thus, to the extent that firms with lower risk of financial misstatement are more likely to adopt clawbacks, the adoption itself does not imply a change in managerial behavior. ${ }^{2}$ In sum, whether firm-initiated clawbacks reduce financial misstatements is ultimately an empirical question.

Using a differences-in-differences approach, we show that, relative to firms without clawbacks, adopting firms experience a significantly larger reduction in the likelihood of misstatements after the adoption. This finding suggests that clawback initiation does not simply serve as a signal, but instead leads to real improvements in reporting integrity.

We next examine how the introduction of clawback provisions affects investors' perception of earnings quality, as indicated by the earnings response coefficient (ERC). We show that, on average, adopting firms' ERCs are higher in the quarters after adoption than in the pre-adoption quarters, and this increase is significantly higher than that observed by firms without clawbacks. Thus, firm-initiated clawbacks appear to enhance the credibility of earnings information.

In a third set of tests we examine how auditors respond to firm-initiated clawbacks. We find that auditors view audit risk as lower after clawback initiation. In particular, relative to firms without clawbacks, both managers and auditors of adopting firms are less likely to report material internal control weaknesses under SOX 404 and 302 after clawback adoption. These results are consistent with managers improving internal controls to prevent restatements and with auditors perceiving companies as associated with lower control risk following clawback adoption. ${ }^{3}$ In addition, relative to firms without clawbacks, clawback adopters experience a significantly larger reduction in audit fees and in the average lag between a client's fiscal year-end and the release of the audit report in the post-adoption period. This implies that auditors exert lower effort and/or assign less experienced staff to the client after clawback adoption.

Taken together, our results show that firm-initiated clawback provisions reduce accounting misstatements and lead to higher earnings quality and lower audit risk as perceived by investors and auditors. The reduction in misstatements is consistent with real improvements in reporting integrity. The increase in perceived earnings quality and reduction in perceived audit risk, however, can be due to either real improvements in reporting integrity or the reactions of investors and auditors to the signal provided by clawback adoption. Subject to this alternative signaling interpretation, our results imply that DFA 954 can be useful, since the requirements of DFA 954 are generally more stringent than those of the clawbacks initiated voluntarily by firms.

As one of the first papers to examine voluntary clawback provisions, our study makes several contributions to the literature. ${ }^{4}$ First, our study shows that firm-initiated clawback provisions mitigate the likelihood of financial misstatements and their negative impacts as documented in many previous studies (e.g., Anderson and Yohn, 2002; Hribar and Jenkins, 2004; Palmrose et al., 2004; Wilson, 2008). Second, our study sheds light on the debate surrounding the practice of tying executive compensation to firm accounting earnings. This practice is criticized for providing managers incentives to manipulate earnings so as to receive excess compensation (e.g., Healy, 1985; Efendi et al., 2007). Our study shows that clawback provisions can help reduce incentives to manipulate earnings arising from compensation considerations.

The rest of the paper is organized as follows. Section 2 provides background on firm-initiated clawbacks and develops our testable hypotheses. Section 3 discusses the sample, and Section 4 discusses our research design and presents the results. Section 5 concludes the paper.

\section{Background and hypotheses}

\subsection{Background on firm-initiated clawbacks}

Compensation recovery provisions were originally introduced by Section 304 of the Sarbanes-Oxley Act (SOX) in 2002. SOX 304 authorizes the SEC to recover bonus or other incentive- or equity-based compensation earned by CEOs and CFOs of

\footnotetext{
2 Based on signaling theory (Farrell and Rabin, 1996), it is costly for firms with lower financial reporting quality to adopt clawbacks as a false signal of financial reporting quality. The reason is that, because firm-initiated clawbacks are written into a manager's compensation (or employment) contract, boards have a legal obligation to enforce them. Thus, it would be costly for low-quality firms to adopt such provisions with no intent of enforcing them in the event of restatements.

${ }^{3}$ Control risk is an auditor's assessment of whether misstatements will be prevented or detected on a timely basis by a client's internal controls (Elder et al., 2009)

${ }^{4}$ Several related studies (e.g., Addy et al., 2009; Brown et al., 2011; Gao et al., 2011) examine the determinants of clawback adoption but not the impacts on financial reporting quality and in turn on investors and auditors, which is the focus of our study.
} 
firms that have to restate financial reports due to misconduct. However, while hundreds of restatements have occurred each year since the passage of SOX (Turner and Weirich, 2006), the SEC did not enforce SOX 304 until July 2009, when it brought charges against the former CEO of CSK Auto Corp. ${ }^{5}$ The SEC's slow enforcement of clawbacks has been largely due to ambiguities in SOX 304. For example, what constitutes material noncompliance and misconduct and whether the CEO and CFO have to be personally involved in the misconduct are both open to interpretation (Salehi and Marino, 2008). Moreover, the SEC is resource constrained and thus can seek recovery only in a limited number of cases (Fried and Shilon, 2011). ${ }^{6}$

The Dodd-Frank Wall Street Reform and Consumer Protection Act, which was enacted in July 2010, also includes a section on the recovery of erroneously awarded compensation. In particular, Section 954 of the Dodd-Frank Act requires listed companies to adopt and implement a policy on the recovery of incentive compensation based on erroneous financial statements. This legislation differs from SOX 304 in that, rather than relying on the SEC, it gives corporate boards a private right of action to recoup bonuses.

While regulators continue to make legislative efforts to mandate clawback policies, a number of companies have instituted their own clawback provisions. According to Corporate Library, 28.4\% of companies in the Russell 1000 index had adopted clawback provisions as of early 2010. The existence of voluntary clawback adopters allows us to test the effectiveness of such provisions in improving financial reporting quality. We next develop testable hypotheses on the effectiveness of firm-initiated clawbacks.

\subsection{The impact of clawback provisions on the likelihood of accounting restatements}

As documented in earlier studies (e.g., Healy, 1985; Holthausen et al., 1995; Burns and Kedia, 2006; Efendi et al., 2007), executives have incentives to manipulate accounting earnings for personal benefit (e.g., to enhance their bonus or to increase the value of their option holdings). Without clawback provisions, when financial misstatements occur the greatest penalty that the board can impose on managers is to replace them (Desai et al., 2006) - the displaced managers can still keep the compensation that they received based on the misstated accounting numbers. With clawback provisions, however, companies impose additional monetary penalties on managers who engage in earnings manipulation, and managers who are disciplined by clawbacks can suffer substantial reputation loss in the labor market. ${ }^{7}$ As such, although the direct monetary effects of clawbacks may not be large, the total disciplinary effects could be substantial. The monetary and reputational penalties are thus likely to mitigate the incentive problems arising from executive compensation: if managers understand that their fraudulent behavior will be penalized ex post through a loss in income, job, and/or reputation, they should have fewer incentives to engage in earnings manipulation ex ante (Desai et al., 2006).

As discussed in Section 2.1, in comparison to SOX 304, which designates the SEC as the sole enforcer of clawbacks, firminitiated clawback provisions are easier to enforce because they authorize a body representing shareholder interests (e.g., the board of directors) to exercise a private right to enforce the clawbacks. Salehi and Marino (2008) observe that it usually takes years for SEC staff to identify, investigate, and file charges against fraudulent activities. Dyck et al. (2010) also show that corporate insiders (such as management or the board of directors) are more likely to detect corporate fraud than the SEC. These arguments suggest that clawback initiation causes a change in managerial behavior (causal effect) and leads to a decline in financial misstatements.

Instead of a causal effect, clawback adoption may have a signaling effect whereby the initiation of clawback provisions signals financial reporting integrity. Because clawback provisions are explicitly written into an executive's compensation (or employment) contract, boards have a legal obligation to enforce them. It is costly for poor-quality firms to adopt such provisions with no intent of enforcing them in the event of restatements. ${ }^{8}$ Thus, only firms with low restatement risk are likely to adopt such provisions. ${ }^{9}$ This explanation suggests that clawback provisions are adopted to help investors or other interested parties identify firms with better reporting quality, not to change managerial behavior. Thus, we would not expect to observe a reduction in restatements during post-adopting periods if clawback provisions are merely adopted by firms with low restatement risk as signals of financial reporting quality. ${ }^{10}$

\footnotetext{
${ }^{5}$ According to the SEC's announcement, this was the first time the commission had invoked SOX 304 to recover compensation from an individual who was not alleged to have committed any other violation of securities laws (SEC, 2009). As of September 2011, the SEC has brought similar charges against current or former CEOs or CFOs of nine more firms, with only five successful cases in total (Morgenson, 2011).

${ }^{6}$ In addition to SOX 304, the federal bailout program implemented under the Emergency Economic Stabilization Act (EESA) of 2008 includes a clause (Section $111(\mathrm{~b})(2)(B)$ ) requiring financial institutions to introduce clawback provisions for the recovery of any bonus or incentive compensation paid to a senior executive officer based on inaccurate earnings (U.S. Department of the Treasury, 2009). However, as the EESA only applies to financial institutions and those institutions differ from industrial firms in many respects, we do not consider this kind of provision in our study. That is, we omit financial firms from our sample.

${ }^{7}$ For example, the clawback of the incentive pay from three executives enforced by Warnaco Group's compensation committee in 2006 appears in The New York Times (Morgenson, 2008). In addition, in its proxy statement filed on April 2, 2010, Skilled Healthcare Group disclosed that the CEO's annual bonus for 2009 was cut by $20 \%$ due to a restatement of the December 31, 2007 and 2008 financial statements announced in June 2009.

${ }^{8}$ In signaling theory (Spence, 1973), a signal is effective only when dishonest signals cannot work. See Farrell and Rabin (1996) and Connelly et al. (2011) for reviews of signaling theory.

${ }^{9}$ For example, a good-quality job candidate is able to signal his superiority over low-quality candidates by pursuing higher education (Spence, 1973). Similarly, firms often communicate their financial health and profitability by borrowing debt and paying dividends (Ross, 1977; Bhattacharya, 1979).

${ }^{10}$ There is another reason why clawback adoption might not lead to a reduction in the frequency of restatements. As in the case of SOX 304 , the definition of misconduct in firm-initiated provisions is often too loose for a company to be certain of winning a lawsuit against an executive. This
} 
To summarize, under the causal argument, clawback adopters should observe a lower likelihood of restatements during post-adoption periods relative to pre-adoption periods, whereas under the signaling argument, clawbacks are not likely to lead to a decrease in misstatements as they are adopted only by firms with better financial reporting quality. ${ }^{11}$ Whether clawback adoption reduces the incidence of restatements is thus an empirical issue. We state our first hypothesis as follows (in alternative form):

H1. The likelihood of financial restatements is lower after the adoption of firm-initiated clawback provisions.

\subsection{Investors' perception of the effectiveness of clawback provisions}

The result we obtain from testing $\mathrm{H} 1$ could be due to auditors perceiving clawback adopters as having a high quality accounting system and in turn reducing efforts to uncover misstatements. To alleviate concerns related to this alternative interpretation, we next consider whether investors perceive clawback provisions to be effective by examining the change in the firm's earnings response coefficient (ERC). According to Kothari (2001) and Dechow et al. (2010), a firm's ERC is often used in accounting studies as a measure of investors' perceived earnings quality. Studies on earnings restatements show that a firm's ERC declines in the quarters following the announcement of a restatement (e.g., Anderson and Yohn, 2002; Wilson, 2008). The decline is interpreted as investors losing confidence in earnings information after the firm has restated its accounts. As discussed above, if clawbacks change managerial behavior (the causal argument), then investors should view the reported accounting earnings of adopting firms as more credible and hence the ERC should be higher subsequent to clawback initiation.

Clawback provisions may also lead to a higher ERC under the signaling argument. If firms with a lower likelihood of accounting restatements adopt clawback provisions to signal their financial reporting quality to investors, then investors should attach more creditability to adopting firms' earnings, leading to a higher ERC after clawback adoption.

This discussion leads to our second hypothesis:

H2. A firm's ERC is higher subsequent to the adoption of clawback provisions.

\subsection{Auditors' perception of the effectiveness of clawback provisions}

\subsubsection{Auditor's assessment of internal controls subsequent to the adoption of clawbacks}

A company's internal controls consist of policies and procedures to reasonably ensure that its financial statements are reliable and free of material mistakes. Starting in 2004, SOX 404 requires managers to assess the effectiveness of their internal control policies and summarize their evaluation in a report included in Form 10-K. SOX 404 also requires that the firm's auditor express an opinion about management's assessment of the internal controls. ${ }^{12}$ Many studies examine the internal control reports disclosed according to SOX 404. These studies document that poorly governed firms are more likely to report material internal control weaknesses and in turn are more likely to have lower financial reporting quality (e.g., Ashbaugh-Skaife et al., 2007; Doyle et al., 2007).

Following the causal argument, we expect that to reduce the likelihood of financial misstatements, managers subject to clawbacks have incentives to improve their internal control systems (Li and Wang, 2006; Plumlee and Yohn, 2009). To the extent that the adoption of clawbacks leads to improved internal controls, auditors are likely to perceive clawbackadopting clients as having lower control risk and thus should be less likely to discover and report material internal control weaknesses for clawback-adopting firms.

Under the signaling argument, auditors may also perceive clawback adopters as associated with lower control risk even if clawback initiation is simply a signal of these firms' financial reporting quality. That is, as long as the signal is credible, clawback initiation communicates new information to auditors that helps them identify firms with better internal controls in place. Based upon this information, auditors should perceive clawback adopters as having lower control risk.

The above arguments lead to our third hypothesis:

H3. A firm is less likely to receive an adverse audit opinion on its internal controls subsequent to the adoption of clawbacks.

\subsubsection{The impact of clawbacks on audit fees and audit report lag}

Prior research shows that audit fees reflect audit risk (Gul and Tsui, 2001; Bedard and Johnstone, 2004). ${ }^{13}$ If auditors observe significant audit risk, they are likely to charge higher fees to cover the extra costs arising from additional audit

(footnote continued)

uncertainty has led the financial media to raise questions about the effectiveness of firm-initiated clawbacks (e.g., Dvorak and Ng, 2006; Weiss, 2009; Lublin, 2010).

${ }^{11}$ If clawbacks are used to signal high reporting quality, clawback adopters should be less likely to have misstatements than non-adopters prior to adoption. As shown later in Section 4.2, we do not find support for this prediction.

12 Before Section 404 took effect, Section 302 of SOX also required that management evaluate the effectiveness of disclosure controls and indicate any significant changes in internal control in Forms $10-\mathrm{K}$ or $10-\mathrm{Q}$, but it did not require that management's evaluation be assessed by external auditors.

${ }^{13}$ Audit risk, the likelihood of material errors in a firm's financial statements that are not detected through the auditing process, is the product of inherent risk, control risk, and detection risk. According to SAS No. 47, inherent risk is the likelihood that material misstatements exist before considering 
effort and/or the assignment of more experienced staff to the audit (Simunic and Stein, 1996). Prior research also documents a positive association between the aggressiveness of financial reporting (or the risk of earnings manipulation) and audit fees (e.g., Phillips, 1999; Beaulieu, 2001; Gul et al., 2003; Hogan and Wilkins, 2008; Hoitash et al., 2008). We posit that audit fees decrease subsequent to the adoption of clawbacks. First, under the causal argument, firm-initiated clawback provisions lead managers to reduce earnings manipulation, which reduces the likelihood of accounting restatements and in turn audit risk. Second, to the extent that clawback provisions provide incentives for managers to prevent future restatements by improving internal controls (H3), fewer internal control deficiencies will be identified by external auditors. Thus, through its effect on control risk, the adoption of clawbacks is likely to result in lower audit risk.

For the same reasons, we expect clawback adoption to shorten the audit report lag, which is the duration between a company's fiscal year-end and the audit report date. Prior studies find that a firm's audit report lag is positively associated with audit risk, suggesting that a firm's audit lag proxies for audit effort and audit risk (e.g., Bamber et al., 1993; Knechel and Payne, 2001; Ettredge et al., 2006; Masli et al., 2010). If auditors are likely to downgrade a client's assessed audit risk following the adoption of clawback provisions, they are also expected to exert lower effort in auditing clawback adopters.

Turning to the signaling argument, we again expect a reduction in both audit fees and audit report lag. As discussed above, clawback initiation helps auditors distinguish clients with a lower likelihood of financial misstatements and in turn lower audit risk, and thus allows auditors to reduce the effort and fees assigned to these firms.

The above arguments lead to our fourth and final hypothesis:

H4. A firm experiences lower audit fees and a shorter audit report lag subsequent to the adoption of clawback provisions.

\section{Sample}

We obtain accounting restatement, material internal control weakness, audit fee, and audit report date data from Audit Analytics, financial data from Compustat and CRSP, clawback provision data from Corporate Library, and corporate governance data from Corporate Library, Execucomp, and Thomson Reuters.

Our initial sample consists of all companies listed in the Russell 3000 Index over the 2000 to 2009 period with available data in Audit Analytics, Compustat, and CRSP. We exclude financial firms from the analysis as financial institutions that received federal bailout funds during the financial crisis in 2008 and 2009 are subject to mandatory clawbacks enforced by the Department of Treasury, whereas our goal is to examine the effect of firms' voluntary initiation of clawback provisions. After excluding financial firms and firms without financial data, our sample consists of 2,183 firms, of which 343 have clawback provisions in place as of 2009. These 343 clawback adopters comprise our treatment sample. The remaining 1,840 firms do not have such provisions in place at any point during our sample period. These non-adopters comprise our control sample. For the 343 clawback firms, we identify the year in which they initiated their clawback policy by searching news announcements and the firms' proxy statements.

Table 1, Panel A presents the yearly distribution of adoptions. As can be seen from the table, clawback provisions were relatively rare (only 18 firms) in 2005. However, the number of firms with such provisions in place jumped to 83 in 2006 , and the practice became even more common during the financial crisis, with 90 and 99 new adopters in 2007 and 2008 , respectively. The total number of adopting firms continued to increase in 2009. As we note earlier, the rise in the number of firms introducing clawback provisions in the post-2006 period could be due in part to the SEC's new regulation requiring disclosure of such provisions.

Panel B of Table 1 presents the industry distribution of clawback adopting firms. As can be seen from the table, clawback adopters are spread fairly evenly across industries. This pattern supports the generalizability of our results.

In Panel C of Table 1, we provide descriptive statistics for the sample used to test hypotheses related to restatements, the disclosure of material internal control weakness, and audit fees and audit report lag (H1, H3, and H4). ${ }^{14}$ The sample spans the 2000 to 2009 period, with 2,652 clawback firm-years and 12,505 non-clawback firm-years. We find that compared to the control firms, clawback firms pay higher audit fees (AuditFee) but have a shorter audit report lag (AuditLag). With respect to financial reporting quality, clawback adopters have a similar likelihood of financial misstatement over the sample period (Restate). ${ }^{15,16}$ In addition, there is no difference in the likelihood of a financial misstatement in the three years prior to each firm-year between the two groups (LagRestate). Turning to firm characteristics, we find that relative to non-adopters, clawback adopters are larger (Size), have higher leverage (Lev), have more operating segments and foreign operations (Segment, Foreign), have better profitability (ROA, Loss), are more likely to engage in M\&A and restructuring activities (Merger, Restructure), have lower sales growth (Growth), are more likely to hire a Big 4 audit firm (Big4), and have lower absolute discretionary accruals (DA). Clawback firms also have smaller quick and complex assets (Quick, InvRec). Finally, in terms of corporate governance, clawback adopters

\footnotetext{
(footnote continued)

the firm's internal controls, control risk is the likelihood that the internal controls will not prevent or detect a material error, and detection risk is the likelihood that the audit procedures fail to detect a material misstatement.

${ }^{14}$ The test of ERC (H2) is based on quarterly data, so we provide descriptive statistics on ERC together with the regression results in Table 3.

${ }^{15}$ The restatement data come from Audit Analytics. To make sure that all of the restatements in our sample are due to the violation of GAAP, following Files et al. (2011) we exclude restatements due to changes in accounting principle, GAAP-to-GAAP changes, and changes in estimates.

${ }^{16}$ For clawback adopters, the mean of Restate is 0.119 during pre-clawback period and 0.013 during post-clawback period. The difference is significant $(t=-9.09)$.
} 
Table 1

Descriptive statistics.

\begin{tabular}{|c|c|c|c|c|}
\hline \multicolumn{5}{|c|}{ Panel A: Number of clawback adopters by year } \\
\hline Year & $\begin{array}{c}\text { Number of firms without } \\
\text { clawback provisions }\end{array}$ & \multicolumn{2}{|c|}{$\begin{array}{l}\text { Number of firms with } \\
\text { clawback provisions }\end{array}$} & $\begin{array}{c}\text { Number of new } \\
\text { adopters }\end{array}$ \\
\hline 2005 & 2,165 & \multicolumn{2}{|c|}{18} & - \\
\hline 2006 & 2,100 & \multicolumn{2}{|c|}{83} & 65 \\
\hline 2007 & 2,010 & \multicolumn{2}{|c|}{173} & 90 \\
\hline 2008 & 1,911 & \multicolumn{2}{|c|}{272} & 99 \\
\hline 2009 & 1,840 & \multicolumn{2}{|c|}{343} & 71 \\
\hline \multicolumn{5}{|c|}{ Panel B: Number of clawback adopters by industry } \\
\hline \multicolumn{2}{|c|}{ Industry (SIC two-digit codes) } & $\begin{array}{l}\text { Total non-financial firms } \\
\text { in the Russell } 3000\end{array}$ & $\begin{array}{c}\text { Firms with clawback } \\
\text { provisions }\end{array}$ & $\begin{array}{c}\% \text { with clawback } \\
\text { provisions }\end{array}$ \\
\hline \multicolumn{2}{|c|}{ Agriculture, forestry, and fishing (01-09) } & 5 & 1 & 20.00 \\
\hline \multicolumn{2}{|c|}{ Mining (10-14) } & 121 & 17 & 14.05 \\
\hline \multicolumn{2}{|c|}{ Construction (15-17) } & 20 & 7 & 35.00 \\
\hline \multicolumn{2}{|c|}{ Manufacturing (20-39) } & 1,045 & 171 & 16.36 \\
\hline \multicolumn{2}{|c|}{ Transportation, communications, and utilities (40-49) } & 286 & 53 & 18.53 \\
\hline \multicolumn{2}{|c|}{ Wholesale trade $(50-51)$} & 73 & 14 & 19.18 \\
\hline \multicolumn{2}{|c|}{ Retail trade (52-59) } & 197 & 34 & 17.26 \\
\hline \multicolumn{2}{|c|}{ Services $(70-88)$} & 436 & 46 & 10.55 \\
\hline \multicolumn{2}{|l|}{ Total } & 2,183 & 343 & 15.71 \\
\hline
\end{tabular}

Panel C: Mean and median firm characteristic

\begin{tabular}{|c|c|c|c|c|c|c|}
\hline & Clawback firms & Control firms & Difference $t$-stat. & Clawback firms & Control firms & Difference $z$-stat. \\
\hline \multicolumn{7}{|c|}{ Sample of regressions on accounting restatements, audit fees and audit lag } \\
\hline Restate & 0.087 & 0.096 & -1.43 & 0.000 & 0.000 & -1.42 \\
\hline AuditFee & 14.527 & 13.817 & $31.60^{* * *}$ & 14.557 & 13.807 & $28.80^{* * *}$ \\
\hline AuditLag & 55.241 & 59.614 & $-7.89 * * *$ & 56.000 & 59.000 & $-12.80^{* * *}$ \\
\hline LagRestate & 0.213 & 0.217 & -0.40 & 0.000 & 0.000 & -0.40 \\
\hline Size & 8.127 & 6.821 & $40.98^{* * *}$ & 8.052 & 6.691 & $35.63^{* *}$ \\
\hline Lev & 0.207 & 0.195 & $2.96^{* * *}$ & 0.183 & 0.160 & $7.22^{* * *}$ \\
\hline Segment & 1.628 & 1.406 & $11.84^{* * *}$ & 1.792 & 1.099 & $12.37^{* * *}$ \\
\hline Loss & 0.178 & 0.248 & $-7.68^{* * *}$ & 0.000 & 0.000 & $-7.66^{* * *}$ \\
\hline Foreign & 0.317 & 0.280 & $3.90^{* * *}$ & 0.000 & 0.000 & $3.89^{* * *}$ \\
\hline Merger & 0.560 & 0.467 & $8.79^{* * *}$ & 1.000 & 0.000 & $8.77^{* * *}$ \\
\hline Restructure & 0.436 & 0.324 & $11.09^{* * *}$ & 0.000 & 0.000 & $11.05^{* * *}$ \\
\hline Growth & 0.110 & 0.153 & $-5.41^{* * *}$ & 0.074 & 0.090 & $-5.71^{* * *}$ \\
\hline$R O A$ & 0.037 & 0.016 & $6.81^{* * *}$ & 0.049 & 0.044 & $5.23^{* * *}$ \\
\hline Quick & 1.598 & 2.238 & $-14.00^{* * *}$ & 1.192 & 1.483 & $-15.98^{* * *}$ \\
\hline $\operatorname{InvRec}$ & 0.510 & 0.561 & $-8.29^{* * *}$ & 0.499 & 0.564 & $-8.65^{* * *}$ \\
\hline$D A$ & 0.067 & 0.082 & $-7.24^{* * *}$ & 0.044 & 0.051 & $-7.38^{* * *}$ \\
\hline Big4 & 0.931 & 0.899 & $5.05^{* * *}$ & 1.000 & 1.000 & $5.04^{* * *}$ \\
\hline AuditorChange & 0.049 & 0.054 & -1.21 & 0.000 & 0.000 & -1.21 \\
\hline InstOwn & 0.603 & 0.525 & $7.70^{* * *}$ & 0.682 & 0.613 & $11.29 * * *$ \\
\hline BoardIndep & 0.674 & 0.633 & $13.06^{* * *}$ & 0.667 & 0.636 & $12.40^{* * *}$ \\
\hline BoardMeet & 8.087 & 7.729 & $4.55^{* * *}$ & 7.000 & 7.000 & $6.68^{* * *}$ \\
\hline AudComSize & 3.543 & 3.283 & $8.58^{* * *}$ & 4.000 & 3.000 & $13.34^{* * *}$ \\
\hline InsideOwn & 0.118 & 0.176 & $-13.74^{* * *}$ & 0.042 & 0.087 & $-21.17^{* * *}$ \\
\hline No. of obs. & 2,652 & 12,505 & & 2,652 & 12,505 & \\
\hline \multicolumn{7}{|c|}{ Sample of regressions on internal control weakness under Section 404} \\
\hline ICW404 & 0.061 & 0.082 & $-2.97^{* * *}$ & 0.000 & 0.000 & $-2.97^{* * *}$ \\
\hline No. of obs. & 1,792 & 8,842 & & 1,792 & 8,842 & \\
\hline
\end{tabular}

The sample period is 2000 to 2009 for regressions on accounting restatements (Restate), audit fees (AuditFee) and audit lag (AuditLag); and 2004 to 2009 for regressions on material internal control weakness (ICW404). Among the 2,652 firm-year observations of clawback adopters, 1,834 and 818 are before and after the initiation of clawbacks, respectively. ${ }^{* *}$ and ${ }^{* * *}$ represent significance at the $5 \%$, and $1 \%$ levels, respectively, based on $t$-statistic for difference in means or based on $z$-statistic for difference in medians. See Appendix B for variable definitions.

have higher institutional investor participation (InstOwn), more independent directors on the board (BoardIndep), more board meetings per year (BoardMeet), a larger audit committee (AudComSize), and lower insider ownership (InsideOwn). Clawback adopters are similar to control firms, however, in terms of auditor turnover (AuditorChange).

To test our hypothesis related to the disclosure of material internal control weakness (H3), we require that clawback adopters and non-adopters both have SOX 404 internal control reports available. Since SOX 404 became effective in 2004, 
tests of this hypothesis are limited to the 2004 to 2009 period. This results in a sample of 1,792 firm-years of clawback adopters and 8,842 firm-years of non-adopters. Panel $\mathrm{C}$ shows that relative to non-adopters, clawback adopters are less likely to have material internal control weaknesses reported by their auditor (ICW404). ${ }^{17}$

\section{Empirical results}

\subsection{Basic research design}

To test our hypotheses, we use the differences-in-differences method following Bertrand and Mullainathan (1999a, 1999b, 2003) and Low (2009). Specifically, we adopt the following research design:

$$
Y_{i t}=\alpha_{0}+\alpha_{1} \text { Clawback }_{i t}+\alpha_{2} \text { AfterClawback }{ }_{i t}+\beta X_{i t}+u_{i}+d_{t}+\varepsilon_{i t},
$$

where $Y$ is the dependent variable of interest (i.e., the probability of a restatement, material internal control weakness, audit fees, and audit lag); Clawback equals one if the company is in the treatment group (clawback adopters) and equals zero if the company is instead in the control group (non-adopters); and AfterClawback equals one for firm-years in which clawback adopters have clawback provisions in place, and zero otherwise. The coefficient on Clawback, $\alpha_{1}$, represents the difference in the dependent variable for clawback adopters and control firms in the pre-adoption period. The coefficient on AfterClawback, $\alpha_{2}$, measures the change in the dependent variable of interest across pre- and post-adoption periods for a clawback firm compared to the change over the same interval for a control firm. $X$ is a vector of control variables. $u_{i}$ and $d_{t}$ are industry- and year-specific fixed effects that account for variation across industries or over time. ${ }^{18}$ Standard errors are adjusted based on the Huber-White sandwich estimate of variances and are clustered by firm.

\subsection{The impact of clawbacks on the occurrence of accounting restatements}

To examine whether the adoption of clawback provisions changes the likelihood of earnings restatement (H1), we estimate the following logistic model, which follows Burns and Kedia (2006) and Efendi et al. (2007):

$$
\begin{aligned}
\text { Restate }_{i t}= & \alpha+\beta_{1} \text { Clawback }_{i t}+\beta_{2} \text { AfterClawback }_{i t}+\beta_{3} \text { LagRestate }_{i t}+\beta_{4} \text { Size }_{i t} \\
& +\beta_{5} \text { Lev }_{i t}+\beta_{6} \text { Segment }_{i t}+\beta_{7} \text { Loss }_{i t}+\beta_{8} \text { Foreign }_{i t}+\beta_{9} \text { Merger }_{i t} \\
& +\beta_{10} \text { Restructure }_{i t}+\beta_{11} \text { InstOwn }_{i t}+\beta_{12} \text { BoardIndep }_{i t}+\beta_{13} \text { BoardMeet }_{i t} \\
& +\beta_{14} \text { AudComSize }_{i t}+\beta_{15} \text { InsideOwn }_{i t}+u_{i}+d_{t}+\varepsilon_{i t},
\end{aligned}
$$

where Restate is a dummy variable that equals one if the company's reported earnings for year $t$ are restated, and zero otherwise; LagRestate equals one if the company's earnings are restated for years $t-1$ to $t-3$, and zero otherwise; Size is the natural logarithm of total assets; Lev is long-term debt divided by total assets; Segment is the natural logarithm of the number of business segments; Loss is a dummy variable that equals one for firms reporting net losses, and zero otherwise; Foreign is a dummy variable that equals one if the company has foreign operations, and zero otherwise; Merger is a dummy variable that equals one if the company is pursuing a merger or acquisition, and zero otherwise; and Restructure is a dummy variable that equals one if the company has undergone restructuring activities, and zero otherwise. ${ }^{19}$ We also include the following four governance measures to control for the impact of corporate governance on the likelihood of accounting restatements: InstOwn, the percentage of shares held by institutional investors; BoardIndep, the percentage of independent directors on the board; BoardMeet, the number of board meetings held per year; and AudComSize, the number of audit committee members. InsideOwn is the percentage of shares held by top management and directors. $u_{i}$ and $d_{t}$ are (2-digit SIC code) industry- and year-specific fixed effects. $z$-statistics are based on the Huber-White sandwich estimate of variances and are adjusted for clustering by firm.

The results of Eq. (2) are presented in Table 2. The coefficient on Clawback is significantly positive $(0.177, z=1.91)$. Since this coefficient represents the difference in the likelihood of misstatements between clawback adopters and control firms in the pre-adoption period, the positive coefficient suggests that clawback adopters are more likely to experience a misstatement than control firms before initiating clawbacks. As discussed in the development of $\mathrm{H} 1$, under the signaling theory, only firms with better financial reporting quality will adopt clawbacks. In other words, those firms using clawbacks as a signal of reporting integrity are expected to have a lower likelihood of misstatements than non-adopters, suggesting a negative coefficient on Clawback. Thus, the positive coefficient on Clawback reported in Table 2 is inconsistent with the signaling theory.

In contrast, the coefficient on AfterClawback is significantly negative $(-1.480, z=-4.17)$. The negative coefficient indicates that clawback adopters' likelihood of having restatements is significantly lower subsequent to clawback

\footnotetext{
${ }^{17}$ For clawback adopters, the mean of ICW404 is 0.095 during pre-clawback period and 0.022 during post-clawback periods, with the difference significant $(t=-6.54)$.

18 Our research design is facilitated by significant cross-sectional and time-series variation in clawback adoption. The cross-sectional variation arises because some firms adopt clawbacks while others do not, while the temporal variation occurs because the firms that voluntarily choose to adopt clawbacks do so at different points in time.

${ }^{19}$ It is possible that firms with a restatement history are less likely to have restatement again in the current period. To address this concern, we include LagRestate to control for the impact of a firm's prior restatements on the likelihood of current restatement.
} 
Table 2

Effect of clawback provisions on the likelihood of accounting restatements (Logit regression).

\begin{tabular}{|c|c|c|c|c|c|}
\hline & \multirow[t]{2}{*}{ Predicted sign } & \multicolumn{2}{|c|}{ All non-adopters as control firms } & \multicolumn{2}{|c|}{ Control firms matched by propensity scores } \\
\hline & & Dep. $=$ Restate & Marginal prob. & Dep. $=$ Restate & Marginal prob. \\
\hline Clawback & + & $\begin{array}{l}0.177^{*} \\
(1.91)\end{array}$ & 0.010 & $\begin{array}{c}0.146 \\
(1.14)\end{array}$ & 0.008 \\
\hline AfterClawback & - & $\begin{array}{l}-1.480^{* * *} \\
(-4.17)\end{array}$ & -0.080 & $\begin{array}{l}-1.216^{* * *} \\
(-2.80)\end{array}$ & -0.060 \\
\hline After & $?$ & - & - & $\begin{array}{l}-1.152^{* * *} \\
(-4.90)\end{array}$ & -0.062 \\
\hline LagRestate & $?$ & $\begin{array}{c}1.683^{* * *} \\
(24.23)\end{array}$ & 0.091 & $\begin{array}{l}1.730^{* * *} \\
(12.95)\end{array}$ & 0.094 \\
\hline Size & - & $\begin{array}{l}-0.089^{* * *} \\
(-3.43)\end{array}$ & -0.005 & $\begin{array}{c}-0.056 \\
(-1.27)\end{array}$ & -0.003 \\
\hline Lev & + & $\begin{array}{c}0.139 \\
(0.83)\end{array}$ & 0.008 & $\begin{array}{r}0.177 \\
(0.58)\end{array}$ & 0.007 \\
\hline Segment & + & $\begin{array}{c}0.042 \\
(0.98)\end{array}$ & 0.002 & $\begin{array}{c}0.018 \\
(0.25)\end{array}$ & 0.001 \\
\hline Loss & + & $\begin{array}{l}0.306^{* * * *} \\
(3.79)\end{array}$ & 0.017 & $\begin{array}{l}0.327^{* *} \\
(2.24)\end{array}$ & 0.017 \\
\hline Foreign & + & $\begin{array}{l}0.200^{* *} \\
(2.55)\end{array}$ & 0.011 & $\begin{array}{c}-0.224 \\
(-1.65)\end{array}$ & -0.013 \\
\hline Merger & + & $\begin{array}{c}0.080 \\
(1.19)\end{array}$ & 0.004 & $\begin{array}{l}-0.025 \\
(-0.20)\end{array}$ & -0.002 \\
\hline Restructure & + & $\begin{array}{l}0.193^{* * *} \\
(2.66)\end{array}$ & 0.010 & $\begin{array}{l}0.308^{* *} \\
(2.38)\end{array}$ & 0.016 \\
\hline InstOwn & - & $\begin{array}{l}-0.139^{*} \\
(-1.68)\end{array}$ & -0.008 & $\begin{array}{l}-0.275 \\
(-1.14)\end{array}$ & -0.005 \\
\hline BoardIndep & - & $\begin{array}{r}0.001 \\
(0.00)\end{array}$ & 0.000 & $\begin{array}{c}0.712 \\
(1.55)\end{array}$ & 0.036 \\
\hline BoardMeet & $?$ & $\begin{array}{l}0.024^{* * *} \\
(2.81)\end{array}$ & 0.001 & $\begin{array}{c}0.004 \\
(0.27)\end{array}$ & 0.000 \\
\hline AudComSize & - & $\begin{array}{l}-0.032 \\
(-1.08)\end{array}$ & -0.002 & $\begin{array}{c}0.043 \\
(1.17)\end{array}$ & 0.002 \\
\hline InsideOwn & + & $\begin{array}{c}0.155 \\
(0.93)\end{array}$ & 0.008 & $\begin{array}{c}0.437 \\
(1.28)\end{array}$ & 0.026 \\
\hline Year and industry fixed effects & & & Yes & & \\
\hline Pseudo- $R^{2}$ & & 0.163 & & 0.151 & \\
\hline No. of obs. & & 15,157 & & 4,074 & \\
\hline
\end{tabular}

In the regression using all non-clawback-adopters as the control firms, the sample has 2,652 firm-year observations belonging to clawback adopters (1,834 firm-years before and 818 firm-years after the initiation of clawbacks) and 12,505 firm-year observations of non-adopters over 2000-2009. In the regression using control firms matched by propensity scores, the sample has 2,045 firm-year observations belonging to clawback adopters (1,376 firmyears before and 669 firm-years after the initiation of clawbacks) and 2,029 firm-year observations of non-adopters over 2000-2009.The $z$-statistics corrected for heteroskedasticity and firm-level clustering of standard errors are reported in parentheses. ${ }^{*},{ }^{* *},{ }^{* * *}$ represent significance at the $10 \%, 5 \%$, and $1 \%$ levels, respectively. See Appendix B for variable definitions.

adoption, after controlling for the change over the same interval for non-adopters. Moreover, the sum of the coefficients on Clawback and AfterClawback is $-1.303(z=-3.73)$, suggesting that clawback adopters have a significantly lower likelihood of restatements in the post-adoption period than control firms, which is not expected from the signaling argument. Taken together, the results in Table 2 support the causal argument, but not the signaling explanation, for clawback adoption.

We conduct two additional tests to verify the robustness of our results. First, as shown in Table 1, clawback adopters are different from control firms along various dimensions. To control for self-selection, we employ the propensity score matching approach (LaLonde, 1986) to create a non-clawback control sample with the closest predicted probabilities of clawback adoption. More specifically, we estimate the clawback adoption probability using a set of variables including firm size, leverage, profitability, market-to-book ratio, number of segments, prior restatements, institutional ownership, board independence, insider ownership, number of board meetings, size of audit committee, industry membership, and dummy variables for each fiscal year. ${ }^{20}$ This matching procedure, which assigns to each control firm an artificial adoption year even though it has never initiated clawbacks, yields 254 pairs of clawback and non-clawback adopters. We then use this matched sample to repeat the estimation of Eq. (2). The results, which are reported in the second column of Table $2,{ }^{21}$

\footnotetext{
${ }^{20}$ Untabulated results suggest that clawback adoption is positively related to firm size and the number of segments and is negatively related to insider ownership.

${ }^{21}$ Because non-clawback control firms based on propensity score matching also have an "artificial" adoption year, we add modify Eq. (2) to include After in the regression analysis.
} 
are qualitatively similar to those reported in the first column. That is, clawback adopters experience a significant reduction in the likelihood of restatements after initiating clawbacks. ${ }^{22}$

Second, we find that on average it takes around 15 months for financial misstatements in our sample to be discovered. That is, if a misstatement is conducted in year $t$, most restatements would be announced in years $t+1$ and $t+2$. It is therefore possible that the reduced occurrence of restatements subsequent to clawback adoption may be driven by the recent nature of our sample period, that is, it is possible that we do not have a long enough sample period for restatements to be discovered. To address this concern, we repeat the estimation of Eq. (2) by restricting the sample period to 2008 (instead of 2009 as in Table 2). This design allows for a two-year detection period for restatements committed in 2008, as AuditAnalytics covers restatements announced up to year 2010. Untabulated results suggest that our conclusions remain unaffected using this shortened sample period. ${ }^{23}$

Taken together, the results in Table 2 suggest that clawback adopters have a lower likelihood of restatements in the post-adoption period compared to the pre-adoption period, relative to firms in the control sample. The other control variables, whenever significant, are consistent with the predicted signs. ${ }^{24}$

\subsection{The impact of clawback provisions on earnings response coefficients}

The previous section shows that clawback initiation significantly decreases misstatements, indicating an improvement in financial reporting quality. To further explore whether this improvement is also perceived by investors, we investigate whether companies that adopt clawback provisions experience an increase in ERC subsequent to the initiation of clawback provisions (H2). To do so, we follow prior ERC studies (e.g., Wilson, 2008) and estimate the following model:

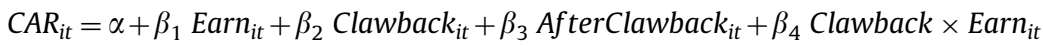

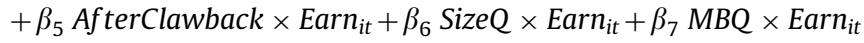

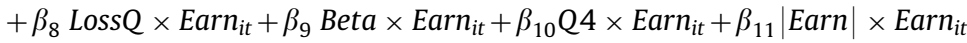

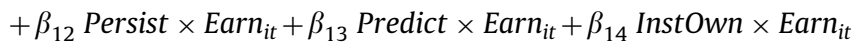

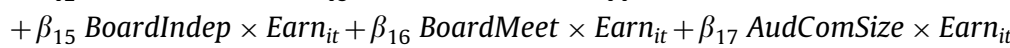

$$
\begin{aligned}
& +\beta_{18} \text { InsideOwn } \times \text { Earn }_{i t}+u_{i}+d_{t}+\varepsilon_{i t}
\end{aligned}
$$

where CAR is the cumulative abnormal return around the quarterly earnings announcement measured over a 3-day window (days -1 to +1 relative to the announcement date); Earn is unexpected quarterly earnings per share deflated by the share price at the beginning of the quarter, where expected earnings are based on the most recent analyst forecast prior to the day before the earnings announcement; SizeQ is the log of the firm's market value of equity at the beginning of the fiscal quarter; $M B Q$ is the market-to-book ratio at the beginning of the fiscal quarter; Loss $Q$ is a dummy variable equal to one if earnings per share in the current quarter is less than zero, and zero otherwise; Beta is systematic risk measured over the year prior to the earnings announcement; Q4 is a dummy variable equal to one if the earnings announcement corresponds to the fourth quarter of the firm's fiscal year, and zero otherwise; |Earn| is a control for nonlinearity; Predict is the variance of expected earnings over the 2-year period prior to the earnings announcement; and Persist is the slope of the time-series seasonal random walk model (Foster, 1977) estimated over the 2-year period prior to the earnings announcement. InstOwn, BoardIndep, BoardMeet, AudComSize, and InsideOwn are defined as for Eq. (2). The regression model includes dummy variables to control for industry and quarter fixed effects. $t$-statistics are based on the HuberWhite sandwich estimate of variances and are adjusted for clustering by firm.

The results of estimating Eq. (3) are presented in Table 3. Panel A of Table 3 reports descriptive statistics for the variables used in Eq. (3) for clawback adopters and non-adopters. We find that relative to non-adopting firms, clawback adopters have a larger earnings surprise (Earn), are larger in size (SizeQ), are less likely to report a loss (LossQ), have smaller beta (Beta), and have larger earnings volatility (Predict).

Panel B presents the regression results. Consistent with prior studies (see Kothari (2001) for a detailed review of the ERC literature), the coefficient on Earn is significantly positive (10.877, $t=17.43$ ). The coefficient on Clawback $\times$ Earn is insignificantly negative $(-0.169, t=-0.54)$, while it is significantly positive on AfterClawback $\times$ Earn $(0.801, t=2.04)$. Since the latter coefficient represents the change in a firm's ERC after adopting clawback provisions compared to the change for control firms over the sample period, its significance suggests that on average adopting firms experience an increase in ERC

\footnotetext{
22 Prior studies document that subsequent to accounting irregularities, firms tend to improve corporate governance to restore financial reporting credibility (e.g., Desai et al. 2006). To rule out the possibility that our results are driven by improvement of other governance mechanisms rather than clawbacks, we examine whether clawback firms experience larger changes in corporate governance than control firms surrounding clawback initiation. Specifically, we compare the changes in several governance mechanisms including board independence, CEO duality, institutional ownership, Big-4 auditor, number of board meetings, insider ownership, and audit committee size across clawback adopters and control firms. We find that relative to control firms, clawback adopters experience similar changes in all the governance variables as control firms during the five-year period surrounding clawback adoption.

${ }^{23}$ The two-year detection period is reasonable as $80 \%$ of restatements announced in 2010 relate to the restatement of earnings for 2008 and 2009.

${ }^{24}$ LagRestate controls for the impact of prior restatements on the likelihood of a restatement in the current year. We find a significantly positive coefficient on LagRestate, suggesting that firms with an accounting restatement in the prior three years are more likely to restate in the current year. This finding is consistent with Files et al. (2011), who show that many restating companies restate repeatedly.
} 
Table 3

Effect of clawback provisions on earnings response coefficients.

\begin{tabular}{|c|c|c|c|c|c|c|}
\hline \multicolumn{7}{|c|}{ Panel A: Mean and median firm characteristic } \\
\hline & $\begin{array}{l}\text { Clawback } \\
\text { firms }\end{array}$ & $\begin{array}{l}\text { Control } \\
\text { firms }\end{array}$ & $\begin{array}{c}\text { Difference } \\
t \text {-stat. }\end{array}$ & $\begin{array}{l}\text { Clawback } \\
\text { firms }\end{array}$ & $\begin{array}{c}\text { Control } \\
\text { firms }\end{array}$ & $\begin{array}{c}\text { Difference } \\
z \text {-stat. }\end{array}$ \\
\hline CAR & 0.005 & 0.006 & -0.81 & 0.003 & 0.004 & -0.596 \\
\hline Earn & 0.000 & 0.000 & $2.56^{* *}$ & 0.000 & 0.000 & 0.319 \\
\hline SizeQ & 8.379 & 7.312 & $63.24^{* * *}$ & 8.272 & 7.174 & $53.51^{* * *}$ \\
\hline$M B$ & 3.191 & 3.185 & 0.13 & 2.497 & 2.320 & $6.54^{* * * *}$ \\
\hline Loss Q & 0.128 & 0.177 & $-10.92^{* * *}$ & 0.000 & 0.000 & $-10.90^{* * *}$ \\
\hline Beta & 1.075 & 1.139 & $-9.57^{* * *}$ & 0.998 & 1.068 & $-10.24^{* * *}$ \\
\hline Q4 & 0.236 & 0.233 & 0.54 & 0.000 & 0.000 & 0.53 \\
\hline Persist & 0.593 & 0.607 & -0.64 & 0.703 & 0.706 & $-1.76^{*}$ \\
\hline Predict & 0.622 & 0.523 & $9.37^{* * *}$ & 0.286 & 0.245 & $11.93^{* * *}$ \\
\hline InstOwn & 0.623 & 0.574 & $7.98^{* * *}$ & 0.706 & 0.692 & $7.87^{* * * *}$ \\
\hline BoardIndep & 0.688 & 0.648 & $22.36^{* * * *}$ & 0.700 & 0.667 & $21.19^{* * *}$ \\
\hline BoardMeet & 7.867 & 7.473 & $9.49^{* * * *}$ & 7.000 & 7.000 & $14.05^{* * *}$ \\
\hline AudComSize & 3.492 & 3.261 & $12.08^{* * *}$ & 4.000 & 3.000 & $19.67^{* * *}$ \\
\hline InsideOwn & 0.110 & 0.159 & $-22.60^{* * *}$ & 0.040 & 0.076 & $-34.80^{* * *}$ \\
\hline
\end{tabular}

Panel B: Regression results

\begin{tabular}{|c|c|c|}
\hline & Predicted sign & Dep. $=C A R$ \\
\hline Earn & + & $\begin{array}{l}10.877^{* * *} \\
(17.43)\end{array}$ \\
\hline Clawback & $?$ & $\begin{array}{l}-0.000 \\
(-0.46)\end{array}$ \\
\hline AfterClawback & $?$ & $\begin{array}{l}-0.002 \\
(-1.27)\end{array}$ \\
\hline Clawback $\times$ Earn & $?$ & $\begin{array}{l}-0.169 \\
(-0.54)\end{array}$ \\
\hline AfterClawback $\times$ Earn & + & $\begin{array}{l}0.801^{* *} \\
(2.04)\end{array}$ \\
\hline SizeQ $\times$ Earn & $?$ & $\begin{array}{l}-0.226^{* * *} \\
(-3.89)\end{array}$ \\
\hline$M B Q \times E a r n$ & + & $\begin{array}{l}0.033^{* *} \\
(2.03)\end{array}$ \\
\hline Loss $Q \times$ Earn & - & $\begin{array}{l}-1.331^{* * *} \\
(-7.27)\end{array}$ \\
\hline Beta $\times$ Earn & - & $\begin{array}{l}-0.295^{* *} \\
(-2.29)\end{array}$ \\
\hline Q4 × Earn & - & $\begin{array}{l}-0.492^{* * *} \\
(-3.06)\end{array}$ \\
\hline $\mid$ Earn $\mid \times$ Earn & - & $\begin{array}{l}-153.364^{* * *} \\
(-24.32)\end{array}$ \\
\hline Persist $\times$ Earn & + & $\begin{array}{l}0.079^{* * * *} \\
(2.88)\end{array}$ \\
\hline Predict $\times$ Earn & - & $\begin{array}{l}-0.079 \\
(-1.20)\end{array}$ \\
\hline InstOwn $\times$ Earn & $?$ & $\begin{array}{l}-0.199 \\
(-1.62)\end{array}$ \\
\hline BoardIndep $\times$ Earn & $?$ & $\begin{array}{l}-1.120^{* *} \\
(-2.05)\end{array}$ \\
\hline BoardMeet $\times$ Earn & $?$ & $\begin{array}{l}-0.040^{* *} \\
(-1.97)\end{array}$ \\
\hline AudComSize $\times$ Earn & $?$ & $\begin{array}{c}0.116^{*} \\
(1.92)\end{array}$ \\
\hline InsideOwn $\times$ Earn & $?$ & $\begin{array}{l}-0.643^{*} \\
(-1.82)\end{array}$ \\
\hline Quarter and industry fixed effects & & Yes \\
\hline $\operatorname{Adj}-R^{2}$ & & 0.101 \\
\hline No. of obs. & & 41,356 \\
\hline
\end{tabular}

The sample has 8,705 firm-quarter observations belonging to clawback adopters (6,154 firm-quarters before and 2,551 firm-quarters after the initiation of clawbacks) and 32,651 firm-quarter observations of non-adopters over 2000-2009. The $t$-statistics corrected for heteroskedasticity and firm-level clustering of standard errors are reported in parentheses. ${ }^{*},{ }^{* *},{ }^{* * *}$ represent significance at the $10 \%, 5 \%$, and $1 \%$ levels, respectively. See Appendix B for variable definitions. 
after introducing clawback provisions and that this change is greater than that for firms that do not have such provisions. The other control variables, where significant, are consistent with the predicted signs.

\subsection{The impact of clawback provisions on the disclosure of internal control weakness}

To investigate whether auditors are less likely to discover and report material internal control weaknesses subsequent to the adoption of clawbacks (H3), we adjust the general model in Eq. (1) to account for a number of firm-level factors that may affect a company's internal control system. The resulting model, presented in Eq. (4), is similar to those used by prior studies on internal control weakness (e.g., Ashbaugh-Skaife et al., 2007; Doyle et al., 2007; Hoitash et al., 2009):

$$
\begin{aligned}
\text { ICW404 }_{i t}= & \alpha_{0}+\alpha_{1} \text { Clawback }_{i t}+\alpha_{2} \text { AfterClawback }_{i t}+\beta_{1} \text { Size }_{i t}+\beta_{2} \text { Growth }_{i t} \\
& +\beta_{3} \text { Segment }_{i t}+\beta_{4} \text { Loss }_{i t}+\beta_{5} \text { Foreign }_{i t}+\beta_{6} \text { Merger }_{i t}+\beta_{7} \text { Restructure }_{i t}+\beta_{8} \text { Auditorchange }_{i t} \\
& +\beta_{9} \text { InstOwn }_{i t}+\beta_{10} \text { BoardIndep }_{i t}+\beta_{11} \text { BoardMeet }_{i t}+\beta_{12} \text { AudComSize }_{i t}+\beta_{13} \text { InsideOwn }_{i t}+u_{i}+d_{t}+\varepsilon_{i t},
\end{aligned}
$$

where the dependent variable, ICW404, equals one if a company is found to have material internal control weaknesses by its auditor in year $t$, and zero otherwise. Clawback and AfterClawback are as defined for Eq. (1). We expect a negative sign on $\alpha_{2}$, the coefficient on AfterClawback. Growth is the one-year percentage growth in sales. We also include AuditorChange, which is equal to one if the firm changes auditors and zero otherwise, as recent auditor changes may be associated with internal control weakness reports (e.g., Zhang et al., 2007; Hoitash et al., 2009). Further, because prior studies show that poorly governed firms are more likely to have internal control weaknesses (e.g., Hoitash et al., 2009), we again add the same five corporate governance variables as in Eqs. (2) to (4), namely, InstOwn, BoardIndep, BoardMeet, AudComSize, and InsideOwn. All other explanatory variables are as defined for Eq. (2). $u_{i}$ and $d_{t}$ are industry- and year-specific fixed effects. The $z$-statistics are based on the Huber-White sandwich estimate of variances and are adjusted for clustering by firm.

Our H3 predicts that clawback adoption leads to fewer adverse audit opinions on internal control quality that are issued according to SOX 404 (i.e., ICW404). The results from estimating Eq. (4) are presented in Table 4. We find that the coefficient on

\begin{tabular}{|c|c|c|c|}
\hline & Predicted sign & Dep. $=I C W 404$ & Marginal prob. \\
\hline Clawback & $?$ & $\begin{array}{r}0.175 \\
(1.37)\end{array}$ & 0.009 \\
\hline AfterClawback & - & $\begin{array}{l}-0.677^{* * *} \\
(-2.59)\end{array}$ & -0.033 \\
\hline Size & - & $\begin{array}{l}-0.192^{* * *} \\
(-5.68)\end{array}$ & -0.009 \\
\hline Growth & + & $\begin{array}{c}-0.058 \\
(-0.47)\end{array}$ & -0.003 \\
\hline Segment & + & $\begin{array}{l}0.184^{* * *} \\
(3.49)\end{array}$ & 0.009 \\
\hline Loss & + & $\begin{array}{l}0.795^{* * * *} \\
(8.74)\end{array}$ & 0.039 \\
\hline Foreign & + & $\begin{array}{l}0.497^{* * * *} \\
(5.69)\end{array}$ & 0.024 \\
\hline Merger & + & $\begin{array}{c}-0.121 \\
(-1.45)\end{array}$ & -0.006 \\
\hline Restructure & + & $\begin{array}{l}0.422^{* * *} \\
(4.91)\end{array}$ & 0.021 \\
\hline AuditorChange & + & $\begin{array}{l}0.530^{* * *} \\
(3.61)\end{array}$ & 0.026 \\
\hline InstOwn & - & $\begin{aligned} & 0.017 \\
- & 0.22\end{aligned}$ & 0.001 \\
\hline BoardIndep & - & $\begin{array}{l}-1.062^{* * *} \\
(-3.67)\end{array}$ & -0.052 \\
\hline BoardMeet & $?$ & $\begin{array}{l}0.040^{* * *} \\
(5.08)\end{array}$ & 0.002 \\
\hline AudComSize & - & $\begin{array}{r}-0.045 \\
(-1.17)\end{array}$ & -0.002 \\
\hline InsideOwn & $?$ & $\begin{array}{c}-0.299 \\
(-1.39)\end{array}$ & -0.015 \\
\hline Year and industry fixed effects & & Yes & \\
\hline Pseudo- $R^{2}$ & & 0.120 & \\
\hline No. of obs. & & 10,634 & \\
\hline
\end{tabular}

Table 4

Effect of clawback provisions on audit opinions on internal control quality under SOX 404 (Logit regression).

The sample has 1,792 firm-year observations belonging to clawback adopters (940 firm-years before and 852 firm-years after the initiation of clawbacks) and 8,842 firm-year observations of non-adopters over 2004-2009. The $z$-statistics corrected for heteroskedasticity and firm-level clustering of standard errors are reported in parentheses. ${ }^{* * *}$ represents significance at the $1 \%$ level. See Appendix B for variable definitions. 
Clawback is positive but insignificant $(0.175, z=1.37)$, suggesting that there is no significant difference in the likelihood of material internal control weaknesses between clawback adopters and non-adopters in the pre-clawback period. The coefficient on AfterClawback, in contrast, is significantly negative $(-0.677, z=-2.59)$, suggesting that the initiation of clawbacks reduces the likelihood of material internal control weaknesses being detected and reported by the auditor. The sum of the coefficients on Clawback and AfterClawback is significantly different from zero $(-0.502, z=-2.13)$. This indicates that relative to firms without clawbacks, clawback adopters are less likely to have material internal control weaknesses reported by the auditor in the post-adoption period. The control variables, whenever significant, are consistent with the predicted signs. Taken together, these results suggest that clawback adopters improve their internal controls, so they are less likely to have material internal control weaknesses following the initiation of clawbacks. ${ }^{25}$

We also reexamine Eq. (4) using ICW302 as the dependent variable. Specifically, ICW302 is equal to one if a company has disclosed material internal control weaknesses in year $t$, and zero otherwise. As indicated in Doyle et al. (2007) and Leone (2007), ICW302 refers to material internal control weaknesses identified and disclosed by managers per Section 302 of SOX. Together with Item 307 of Regulation S-K, managers are required to disclose an identified material internal control weakness whenever they observe such weakness. The result on ICW302 should therefore complement the result on ICW404 by shedding light on whether managers do indeed take actions to improve internal controls after clawback provisions are initiated. We find that using ICW302 as the dependent variable yields very similar results as reported in Table 4, that is, clawback initiation leads to a lower likelihood of material internal control weakness being disclosed by managers. Thus, taken together with the result on ICW404, clawback provisions appear to motivate managers to improve internal controls to prevent restatements.

\subsection{The impact of clawback provisions on audit fees and audit lag}

To test for the effect of clawback provisions on audit effort as proxied by audit fees and audit report lag (H4), we examine the following model, which is consistent with prior studies on audit fees (e.g., Simunic, 1980; Francis, 1984; Schwartz and Soo, 1996; Ashbaugh-Skaife et al., 2003; Whisenant et al., 2003; Ettredge et al., 2006):

$$
\begin{aligned}
\text { AuditFee }_{i t}\left(\text { AuditLag }_{i t}\right)= & \alpha_{0}+\alpha_{1} \text { Clawback }_{i t}+\alpha_{2} \text { AfterClawback }_{i t}+\beta_{1} \text { Size }_{i t}+\beta_{2} \text { Growth }_{i t} \\
& +\beta_{3} \text { Leverage }_{i t}+\beta_{4} \text { ROA }_{i t}+\beta_{5} \text { Quick }_{i t}+\beta_{6} \text { InvRec }_{i t}+\beta_{7} \text { Segment }_{i t} \\
& +\beta_{8} \text { DA }_{i t}+\beta_{9} \text { Loss }_{i t}+\beta_{10} \text { Foreign }_{i t}+\beta_{11} \text { Merger }_{i t}+\beta_{12} \text { Big4 }_{i t} \\
& +\beta_{13} \text { AuditorChange }_{i t}+\beta_{14} \text { YearEnd }_{i t}+\beta_{15} \text { InstOwn }_{i t} \\
& +\beta_{16} \text { BoardIndep }_{i t}+\beta_{17} \text { BoardMeet }_{i t}+\beta_{18} \text { AudComSize }_{i t}+\beta_{19} \text { InsideOwn }_{i t}+u_{i}+d_{t}+\varepsilon_{i t},
\end{aligned}
$$

where AuditFee is the natural logarithm of audit fees and AuditLag is the number of days between a company's fiscal yearend and the audit report date. Clawback and AfterClawback are as previously defined. We again expect a negative sign on $\alpha_{2}$, the coefficient on AfterClawback. Variables new to this model are as follows: ROA is income before extraordinary items divided by lagged total assets; Quick is the ratio of current assets minus inventories to current liabilities; and InvRecis inventory and receivables divided by total assets. In line with previous research (e.g., Whisenant et al., 2003), we predict that audit fees are increasing in firm size, complexity, and leverage, and decreasing in profitability and liquidity. We also include in the fees model the absolute value of performance-adjusted discretionary accruals $(D A)$, calculated following Ashbaugh-Skaife et al. (2008). ${ }^{26}$ We expect that audit fees are positively associated with absolute discretionary accruals (e.g., Gul et al., 2003; Hogan and Wilkins, 2008). Finally, we include YearEnd, which is equal to one for firms with nonDecember 31 fiscal year-ends, to control for off-peak pricing of audit services, and Big4, which is equal to one for firms using Big 4 auditors, to control for audit quality (Gul and Goodwin, 2010). All other explanatory variables are as defined earlier. The $t$-statistics are based on Huber-White sandwich estimate of variances and are adjusted for clustering by firm.

The results from estimating Eq. (5) are provided in Table 5. In the first column, where the dependent variable is AuditFee, we find that the coefficient on Clawback is significantly positive $(0.057, t=3.96)$, suggesting that clawback adopters pay higher audit fees before the adoption of clawbacks as compared to firms in the control sample. The coefficient on AfterClawback, however, is significantly negative $(-0.067, t=-3.21)$, suggesting that adopting firms' audit fees decrease after the initiation of clawbacks. More specifically, the coefficient of -0.067 implies that the introduction of clawback provisions corresponds to a 6.5\% decrease in audit fees. The sum of Clawback and AfterClawback is -0.010 and is not significantly different from zero $(t=-0.53)$. This suggests that clawback adopters pay higher audit fees than control firms before the initiation of clawbacks, whereas they pay similar audit fees as control firms after the adoption of clawbacks. The control variables, whenever significant, take the predicted signs. These results are consistent with the introduction of firm-initiated clawbacks leading to lower audit fees.

Turning to the second column, which presents the results using AuditLag as the dependent variable, we again find that the coefficient on Clawback is positive but insignificant $(0.564, t=0.79)$, indicating that clawback adopters have a similar audit lag as control firms in the pre-adoption period. In contrast, AfterClawback is significantly negative $(-1.623, t=-2.07)$,

\footnotetext{
25 To check the robustness of our findings, we re-estimate Eq. (4) using the continuous variable NICW404, the number of material internal control weaknesses reported by the auditor in year $t$, as the dependent variable instead of the dummy variable ICW404. Because NICW404 is a count variable, we employ a Poisson regression (Kennedy, 2008). Untabulated results show that our findings remain qualitatively the same. In particular, the coefficient on Clawback is negative but insignificant $(-0.096, t=-0.60)$, while the coefficient on AfterClawback is significantly negative $(-0.688, t=-2.25)$.

${ }^{26}$ Kothari et al. (2005) show that matching on performance enhances the reliability of inferences in earnings management studies.
} 
Table 5

Effect of clawback provisions on audit fees and audit lag.

\begin{tabular}{|c|c|c|c|c|}
\hline & Predicted sign & Dep. $=$ AuditFee & Predicted sign & Dep. $=$ AuditLag \\
\hline Clawback & $?$ & $\begin{array}{l}0.057^{* * *} \\
(3.96)\end{array}$ & $?$ & $\begin{array}{c}0.564 \\
(0.79)\end{array}$ \\
\hline AfterClawback & - & $\begin{array}{l}-0.067^{\text {**** }} \\
(-3.21)\end{array}$ & - & $\begin{array}{l}-1.623^{*} \\
(-2.07)\end{array}$ \\
\hline Size & + & $\begin{array}{c}0.522^{* * *} \\
(136.13)\end{array}$ & - & $\begin{array}{l}-2.507^{* * * *} \\
(-13.90)\end{array}$ \\
\hline Growth & $?$ & $\begin{array}{l}-0.098^{* * *} \\
(-7.04)\end{array}$ & $?$ & $\begin{array}{l}2.298^{* * *} \\
(2.59)\end{array}$ \\
\hline Lev & + & $\begin{array}{l}0.129^{* * *} \\
(4.62)\end{array}$ & + & $\begin{array}{l}3.889^{* * * *} \\
(3.23)\end{array}$ \\
\hline$R O A$ & - & $\begin{array}{l}-0.167^{* * *} \\
(-3.93)\end{array}$ & - & $\begin{array}{l}-6.640^{* * *} \\
(-2.83)\end{array}$ \\
\hline Quick & - & $\begin{array}{l}-0.058^{* * * *} \\
(-22.20)\end{array}$ & - & $\begin{array}{l}-0.788^{* * *} \\
(-7.07)\end{array}$ \\
\hline $\operatorname{InvRec}$ & + & $\begin{array}{c}0.540^{\text {**** }} \\
(21.04)\end{array}$ & + & $\begin{array}{c}0.448 \\
(0.40)\end{array}$ \\
\hline Segment & + & $\begin{array}{l}0.036^{* * * *} \\
(6.31)\end{array}$ & + & $\begin{array}{c}0.196 \\
(0.79)\end{array}$ \\
\hline$D A$ & + & $\begin{array}{c}0.062 \\
(1.08)\end{array}$ & + & $\begin{array}{l}7.568^{* * * *} \\
(2.75)\end{array}$ \\
\hline Loss & + & $\begin{array}{l}0.094^{* * *} \\
(6.58)\end{array}$ & + & $\begin{array}{l}3.367^{* * * *} \\
(4.39)\end{array}$ \\
\hline Foreign & + & $\begin{array}{l}0.196^{* * *} \\
(19.55)\end{array}$ & + & $\begin{array}{l}2.850^{* * *} \\
(5.97)\end{array}$ \\
\hline Merger & + & $\begin{array}{l}0.078^{* * *} \\
(8.38)\end{array}$ & + & $\begin{array}{l}0.914^{* *} \\
(2.24)\end{array}$ \\
\hline Big4 & + & $\begin{array}{l}0.095^{* * *} \\
(5.60)\end{array}$ & - & $\begin{array}{c}0.033 \\
(0.05)\end{array}$ \\
\hline AuditorChange & - & $\begin{array}{l}-0.084^{* * *} \\
(-3.86)\end{array}$ & + & $\begin{array}{l}1.768^{*} \\
(1.65)\end{array}$ \\
\hline YearEnd & + & $\begin{array}{c}0.167^{* * * *} \\
(16.43)\end{array}$ & $?$ & $\begin{array}{l}0.986^{* *} \\
(1.97)\end{array}$ \\
\hline InstOwn & $?$ & $\begin{array}{r}-0.011 \\
(-1.39)\end{array}$ & $?$ & $\begin{array}{r}0.121 \\
(0.34)\end{array}$ \\
\hline BoardIndep & $?$ & $\begin{array}{l}0.201^{* * * *} \\
(6.30)\end{array}$ & $?$ & $\begin{array}{l}-6.108^{* * *} \\
(-4.32)\end{array}$ \\
\hline BoardMeet & $?$ & $\begin{array}{l}0.018^{* * *} \\
(13.95)\end{array}$ & $?$ & $\begin{array}{l}0.249^{* * *} \\
(4.25)\end{array}$ \\
\hline AudComSize & $?$ & $\begin{array}{r}-0.005 \\
(-1.31)\end{array}$ & $?$ & $\begin{array}{c}-0.204 \\
(-1.22)\end{array}$ \\
\hline InsideOwn & $?$ & $\begin{array}{l}-0.103^{* * *} \\
(-4.10)\end{array}$ & $?$ & $\begin{array}{l}3.368^{* * *} \\
(3.13)\end{array}$ \\
\hline Year and industry fixed effects & & Yes & & Yes \\
\hline Adj- $R^{2}$ & & 0.773 & & 0.200 \\
\hline No. of obs. & & 15,157 & & 15,157 \\
\hline
\end{tabular}

The sample has 2,652 firm-year observations belonging to clawback adopters (1,834 firm-years before and 818 firm-years after the initiation of clawbacks) and 12,505 firm-year observations of non-adopters over 2000-2009. The $t$-statistics corrected for heteroskedasticity and firm-level clustering of standard errors are reported in parentheses. ${ }^{*},{ }^{* *}, *^{* *}$ represent significance at the $10 \%, 5 \%$, and $1 \%$ levels, respectively. See Appendix B for variable definitions.

suggesting that clawbacks lead to a reduction in auditor effort. The sum of Clawback and AfterClawback is significantly different from zero $(-1.059, t=-2.10)$, which indicates that clawback adopters have shorter audit report lags in the post-adoption period compared to firms without clawbacks. The control variables, whenever significant, are consistent with the predicted signs.

Taken together, the results in Table 5 indicate that clawbacks reduce audit risk and thus allow auditors to charge lower audit fees and exert lower effort as proxied by audit report lag.

\subsection{Additional robustness tests}

To verify the robustness of our results, we again use the control group based on propensity matching (as described in Section 4.2) to repeat the estimation of Eqs. (3)-(5). The results are provided in Table 6. To save space, we only present the abbreviated results on the main variables of interest, namely, Clawback, AfterClawback, and After. The results are generally similar to those reported in Tables 3-5. In particular, the introduction of firm-initiated clawbacks enhances earnings quality as perceived by investors, decreases material internal control weaknesses, and cuts auditor effort as proxied by audit fees and audit report lag. 
Table 6

Robust tests: regression results using a matched-pair design based on the propensity score.

\begin{tabular}{|c|c|c|c|c|}
\hline & \multicolumn{4}{|l|}{ Dep. $=$} \\
\hline & CAR & ICW404 & AuditFee & AuditLag \\
\hline Clawback & $\begin{array}{r}0.001 \\
(0.87)\end{array}$ & $\begin{array}{c}0.339 \\
(1.52)\end{array}$ & $\begin{array}{l}0.049^{* *} \\
(2.06)\end{array}$ & $\begin{array}{c}1.691 \\
(1.36)\end{array}$ \\
\hline AfterClawback & $\begin{array}{l}-0.005^{*} \\
(-1.82)\end{array}$ & $\begin{array}{l}-0.902^{* *} \\
(-2.25)\end{array}$ & $\begin{array}{c}-0.062^{*} \\
(-1.71)\end{array}$ & $\begin{array}{l}-3.490^{* *} \\
(-2.13)\end{array}$ \\
\hline After & $\begin{array}{r}-0.002 \\
(-1.15)\end{array}$ & $\begin{array}{l}-0.475^{*} \\
(-1.80)\end{array}$ & $\begin{array}{c}0.368^{* * *} \\
(13.68)\end{array}$ & $\begin{array}{l}5.155^{* *} \\
(3.91)\end{array}$ \\
\hline Clawback $\times$ Earn & $\begin{array}{c}-0.184 \\
(-0.43)\end{array}$ & & & \\
\hline AfterClawback $\times$ Earn & $\begin{array}{l}1.093^{* *} \\
(2.06)\end{array}$ & & & \\
\hline After $\times$ Earn & $\begin{array}{c}-0.292 \\
(-0.76)\end{array}$ & & & \\
\hline Control variables & Yes & Yes & Yes & Yes \\
\hline Pseudo- $R^{2} / \mathrm{Adj}-R^{2}$ & 0.096 & 0.082 & 0.732 & 0.141 \\
\hline No. of obs. & 13,295 & 2,774 & 4,074 & 4,074 \\
\hline
\end{tabular}

The propensity score-matching method produces 254 matched-pairs of clawback firms and control firms. The propensity scores are calculated using variables significant in determining whether a firm has adopted the clawback provisions, including firm size, leverage, profitability, market-to-book ratio, segments, prior restatements, institutional ownership, board independence and duality of CEO-Chairman. The $t$-statistics ( $z$-statistics) corrected for heteroskedasticity and firm-level clustering of standard errors are reported in parentheses. ${ }^{*},{ }^{* *},{ }^{* * *}$ represent significance at the $10 \%, 5 \%$, and $1 \%$ levels, respectively. See Appendix B for variable definitions.

In addition, we examine whether clawback provisions are associated with a reduction in non-audit fees. If the decrease in audit fees that we document for clawback adopters is driven by these firms' lower audit risk, we would not expect to observe a reduction in non-audit fees subsequent to the initiation of clawbacks (DeFond et al., 2002). To test this conjecture, we re-estimate Eq. (5) using NonAuditFee (the natural log of non-audit fees paid to the auditor) as the dependent variable. We find that the coefficient on AfterClawback is statistically insignificant $(0.061, t=0.97)$, suggesting that the initiation of clawbacks does not affect non-audit fees. This result further supports the view that the introduction of firm-initiated clawbacks leads to reduced audit risk.

\section{Conclusions}

In this study we examine whether firm-initiated clawback provisions, policies that allow firms to recoup compensation from managers in the event of accounting restatements, enhance earnings quality and reduce audit risk. Using Russell 3000 non-financial firms to form our sample of clawback adopters and non-adopters, we first show that the incidence of accounting restatements declines significantly after the initiation of clawbacks. This implies that managers have lower incentives to engage in earnings manipulation when they are subject to clawbacks. We also show that investors consider clawback adopters' earnings to be more credible as reflected by a higher ERC subsequent to the adoption of clawbacks.

Further, we find that auditors are less likely to identify and report material internal control weaknesses after the initiation of clawbacks. This implies that auditors perceive managers subject to clawbacks as having incentives to prevent financial misstatements by improving internal control systems. Moreover, both audit fees and audit lags decline after a client initiates clawback provisions (relative to the pre-adoption period and to changes over the same period in nonadopting firms), which suggests that the improvement in internal control systems induced by clawbacks reduces audit risk and thus allows auditors to exert less audit effort.

Our finding of a reduction in misstatements for clawback adopters is consistent with real improvements in reporting integrity. The results on perceived earnings quality and audit risk, however, can be due to either real improvements in reporting integrity or the reactions of investors and auditors to the signal associated with clawback adoption. The reason is that firms with high accounting quality might use voluntary clawbacks to signal their superior quality, and in response auditors and investors might react to the signal in their assessment of the quality of the accounting system.

Our study is subject to several limitations. First, the 2010 Dodd-Frank Act mandates all listed firms to adopt clawback provisions (Section 954, or DFA 954). Since DFA 954 designates enforcement to boards of directors and does not require the existence of misconduct, it can be expected to be useful in improving financial reporting quality. However, because DFA 954 is mandatory and applies to all listed firms, the clawbacks under this Act do not have a signaling effect. Our results, however, could be due to a signaling effect, and hence our results should be interpreted with this alternative interpretation in mind. In addition, it is not clear that boards of directors of companies that do not initiate clawbacks voluntarily would enforce clawbacks as effectively as boards of voluntary adopters. Finally, because firm-initiated clawbacks have become common only since 2005, our conclusions are based on a relatively short post-adoption period. As a result, we are not able to observe a large number of 
related incidents such as the enforcement of clawback provisions, auditors' going-concern opinions, or auditor changes. Future research could reexamine these issues using a longer sample period.

\section{Appendix A. Examples of clawback provisions included in the proxy statements}

\section{Example 1. Exxon Mobil}

Clawback provision in Exxon Mobil 's proxy statement filed on May 28, 2008 (p. 28): Should the Corporation's reported financial or operating results be subject to a material negative restatement within five years, the Board would seek to obtain from each executive officer an amount corresponding to any incentive award or portion thereof that the Board determines would not have been granted or paid had the Corporation's results as originally reported been equal to the Corporation's results as subsequently restated.

\section{Example 2. GAP Inc.}

Clawback provision in GAP Inc.'s proxy statement filed on April 26, 2007 (pp. 32-33): In February 2007, the Company established a policy covering recovery and adjustments to awards in connection with financial restatements resulting from the misconduct of an executive. It is the Company's policy that, subject to the discretion and approval of the Board, the Company will, to the extent permitted by governing law, in all appropriate cases as determined by the Board, require reimbursement and/or cancellation of any bonus or other incentive compensation, including stock-based compensation, awarded to an executive officer or other member of the Company's executive leadership team after April 1, 2007 where all of the following factors are present: (a) the award was predicated upon the achievement of certain financial results that were subsequently the subject of a restatement, (b) in the Board's view, the executive engaged in fraud or intentional misconduct that was a substantial contributing cause to the need for the restatement, and (c) a lower award would have been made to the executive based upon the restated financial results. In each such instance, the Company will seek to recover the individual executive's entire annual bonus or award for the relevant period, plus a reasonable rate of interest.

\section{Appendix B}

See Table B1.

Table B1

Variable definition.

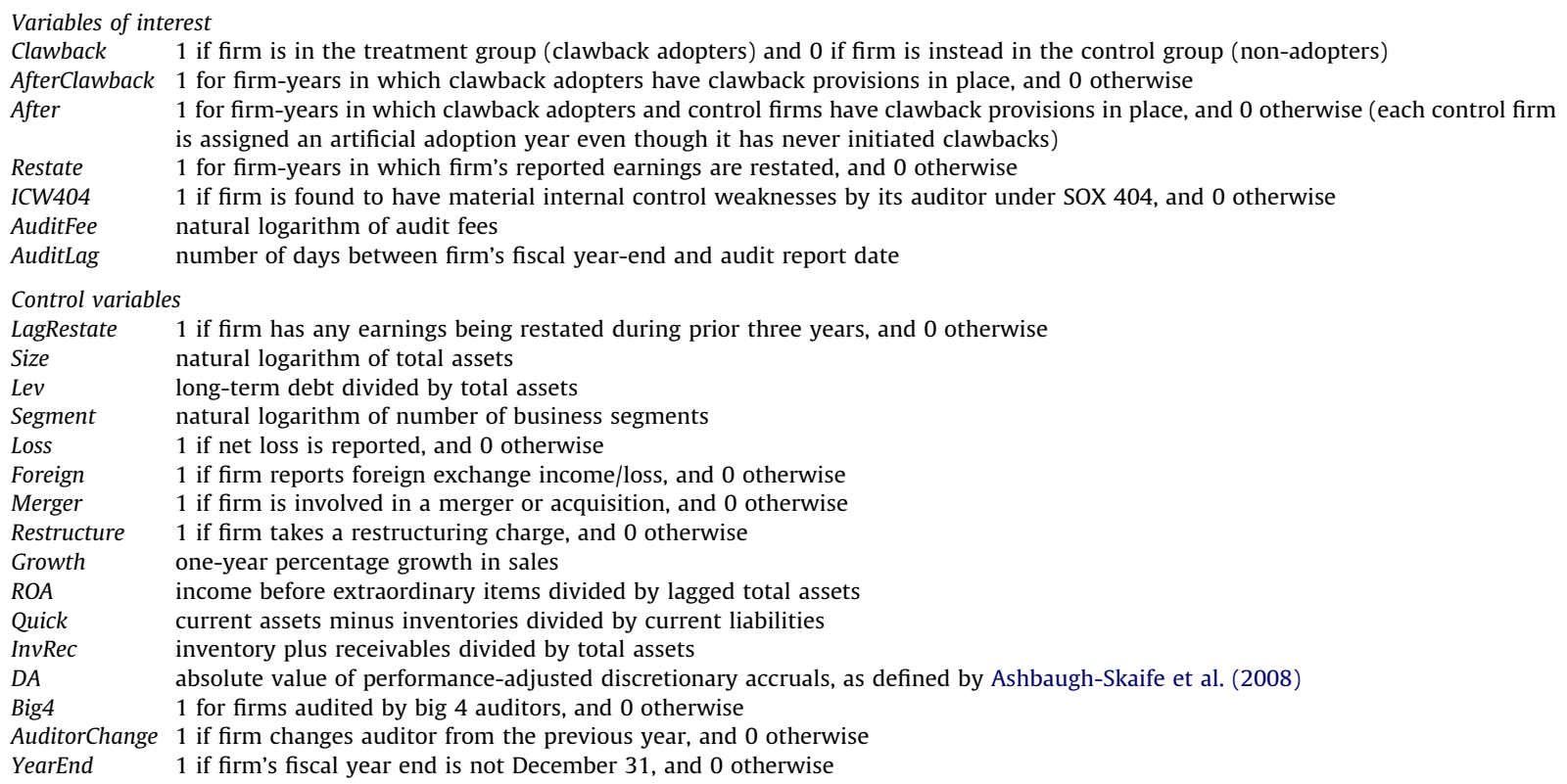


Table B1 (continued)

\begin{tabular}{|c|c|}
\hline InstOwn & percentage of shares held by institutional owners \\
\hline BoardIndep & percentage of independent directors on the board \\
\hline BoardMeet & number of board meetings \\
\hline AudComSize & number of audit committee members \\
\hline InsideOwn & percentage of shares held by top management and directors \\
\hline \multicolumn{2}{|c|}{ Variables for earnings response coefficient regression } \\
\hline CAR & cumulative abnormal return surrounding the earnings announcement, measured over a 3-day window \\
\hline Earn & $\begin{array}{l}\text { unexpected quarterly earnings per share deflated by the share price at the beginning of the quarter, where expected earnings are } \\
\text { based on the most recent analyst forecast prior to the day before the earnings announcement }\end{array}$ \\
\hline SizeQ & $\log$ of market value of equity at the beginning of the fiscal quarter \\
\hline$M B$ & market-to-book ratio at the beginning of the fiscal quarter \\
\hline Loss $Q$ & 1 if earnings per share in the quarter are less than zero and 0 otherwise \\
\hline Beta & systematic risk measured over the year prior to the earnings announcement \\
\hline $\begin{array}{l}\text { Q4 } \\
\mid \text { Earn } \mid\end{array}$ & $\begin{array}{l}1 \text { if the earnings announcement is for the fourth quarter of the firm's fiscal year and } 0 \text { otherwise } \\
\text { absolute value of Earn }\end{array}$ \\
\hline Persist & $\begin{array}{l}\text { slope coefficient from the time-series seasonal random walk model (Foster, 1977) estimated over the two-year period prior to the } \\
\text { earnings announcement }\end{array}$ \\
\hline Predict & $\begin{array}{l}\text { standard deviation of unexpected earnings over the two-year period prior to the earnings announcement, where unexpected earnings } \\
\text { is change of earnings per share from current quarter to the same quartet of the prior year }\end{array}$ \\
\hline
\end{tabular}

\section{References}

Addy, N., Chu, X., Yoder, T., 2009. Recovering Bonuses After Restated Financials: Adopting Clawback Provisions. Working Paper. Mississippi State University.

Anderson, K., Yohn, T., 2002. The Effect of 10K Restatements on Firm Value, Information Asymmetries, and Investors' Reliance on Earnings. Working Paper. Georgetown University.

Ashbaugh-Skaife, H., Collins, D., Kinney, W., 2007. The discovery and reporting of internal control deficiencies prior to SOX-mandated audits. Journal of Accounting and Economics 44, 166-192.

Ashbaugh-Skaife, H., Collins, D., Kinney, W., LaFond, R., 2008. The effect of SOX internal control deficiencies and their remediation on accruals quality. The Accounting Review 83, 217-250.

Ashbaugh-Skaife, H., LaFond, R., Mayhew, B., 2003. Do non-audit services compromise auditor independence? Further evidence. The Accounting Review 78, 611-639.

Bamber, E., Bamber, L., Schoderbek, M., 1993. Audit structure and other determinants of audit report lag: an empirical analysis. Auditing: A Journal of Practice \& Theory $12,1-23$.

Beaulieu, P.R., 2001. The effects of judgments of new clients' integrity upon risk judgments, audit evidence, and fees. Auditing: A Journal of Practice $\&$ Theory 20, 85-99.

Bedard, J.C., Johnstone, K.M., 2004. Earnings manipulation risk, corporate governance risk, and auditors' planning and pricing decisions. The Accounting Review 79, 277-304

Bertrand, M., Mullainathan, S., 1999a. Corporate Governance and Executive Pay: Evidence from Takeover Legislation. Working Paper. University of Chicago.

Bertrand, M., Mullainathan, S., 1999b. Is there discretion in wage setting? A test using takeover legislation. RAND Journal of Economics 30, 535-554.

Bertrand, M., Mullainathan, S., 2003. Enjoying the quiet life? Corporate governance and managerial preferences. Journal of Political Economy 111, 1043-1075.

Bhattacharya, S., 1979. Imperfect information, dividend policy, and the 'bird in the hand' fallacy. Bell Journal of Economics $10,259-270$.

Brown, A., Davis-Friday, P., Guler, L., 2011. Economic Determinants of the Voluntary Adoption of Clawback Provisions in Executive Compensation Contracts. Working Paper. Baruch College.

Burns, N., Kedia, S., 2006. The impact of performance-based compensation on misreporting. Journal of Financial Economics 79 , 35-67.

Connelly, B.L., TrevisCerto, S, Ireland, R.D., Reutzel, C.R., 2011. Signaling theory: a review and assessment. Journal of Management 37, 39-67.

Dechow, P., Ge, W., Schrand, C., 2010. Understanding earnings quality: a review of the proxies, their determinants and their consequences. Journal of Accounting and Economics 50, 344-401.

DeFond, M., Raghunandan, K., Subramanyam, K.R., 2002. Do non-audit service fees impair auditor independence? Evidence from going concern audit opinions. Journal of Accounting Research 40, 1247-1274.

Desai, H., Hogan, C., Wilkins, M., 2006. The reputational penalty for aggressive accounting: Earnings restatement and management turnover. The Accounting Review 81, 83-112.

Doyle, J., Ge, W., McVay, S., 2007. Determinants of weaknesses in internal control over financial reporting. Journal of Accounting and Economics 44, $193-223$.

Dyck, A., Morse, A., Zingales, L., 2010. Who blows the whistle on corporate fraud? Journal of Finance 65, 2213-2253.

Dvorak, P., Ng., S., 2006. Check, Please: reclaiming pay from executives is tough to do. The Wall Street Journal, 20.

Efendi, J., Srivastava, A., Swanson, E., 2007. Why do corporate managers misstate financial statements? The role of option compensation and other factors. Journal of Financial Economics 85, 667-708.

Elder, R., Zhang, Y., Zhou, J., Zhou, N., 2009. Internal control weaknesses and client risk management. Journal of Accounting, Auditing and Finance 24, 543-579.

Ettredge, M.L., Li, C., Sun, L., 2006. The impact of SOX Section 404 internal control quality assessment on audit delay in the SOX era. Auditing: A Journal of Practice \& Theory 25, 1-23.

Farrell, J., Rabin, M., 1996. Cheap talk. Journal of Economic Perspectives 10, 103-118.

Files, R., Sharp, N.Y., Thompson, A., 2011. Why do Firms Restate Repeatedly? Working Paper. University of Texas at Dallas.

Foster, G., 1977. Quarterly accounting data: time-series properties and predictive-ability results. The Accounting Review 52, 1-21.

Francis, J., 1984. The effect of audit firm size on audit prices: a study of the Australian market. Journal of Accounting and Economics 6, $133-151$.

Fried, J., Shilon, N., 2011. Excess-pay Clawbacks. Working Paper. Harvard Law School.

Gao, X., Iskandar-Datta, M., Jia Y., 2011. Piercing the Corporate Veil: The Case for Clawback Provisions. Working Paper. Wayne State University.

Gul, F., Chen, C., Tsui, J., 2003. Discretionary accounting accruals, managers' incentives, and audit fees. Contemporary Accounting Research 20, 441-464.

Gul, F., Goodwin, J., 2010. Short-term debt maturity structures, credit ratings, and the pricing of audit services. The Accounting Review 85, 877-909. 
Gul, F., Tsui, J., 2001. Free cash flow, debt monitoring, and audit pricing: further evidence on the role of director equity ownership. Auditing: A Journal of Practice \& Theory 20, 71-84.

Healy, P.M., 1985. The effect of bonus schemes on accounting decisions. Journal of Accounting and Economics7, 85-107.

Hogan, C., Wilkins, M., 2008. Evidence on the audit risk model: do auditors increase audit effort in the presence of internal control weaknesses? Contemporary Accounting Research 25, 219-242.

Hoitash, R., Hoitash, U., Bedard, J., 2008. Internal control quality and audit pricing under the Sarbanes-Oxley Act. Auditing: A Journal of Practice \& Theory $27,105-126$.

Hoitash, R., Hoitash, U., Bedard, J., 2009. Corporate governance and internal control over financial reporting: a comparison of regulatory regimes. The Accounting Review 84, 839-867.

Holthausen, R.W., Larcker, D.F., Sloan, R.G., 1995. Annual bonus schemes and the manipulation of earnings. Journal of Accounting and Economics 19, 29-74.

Hribar, P., Jenkins, N., 2004. The effect of accounting restatements on earnings revisions and the estimated cost of capital. Review of Accounting Studies 9 , 337-356.

Kennedy, P., 2008. A Guide to Econometrics. Blackwell Publishing.

Knechel, W., Payne, J., 2001. Additional evidence on audit report lag. Auditing: A Journal of Practice \& Theory 20, 137-146.

Kothari, S.P., 2001. Capital markets research in accounting. Journal of Accounting and Economics 31, 105-231.

Kothari, S.P., Leone, A.J., Wasley, C.E., 2005. Performance-matched discretionary accrual measures. Journal of Accounting and Economics 39, 163-197.

LaLonde, R., 1986. Evaluating the econometric evaluations of training programs with experimental data. American Economic Review 76, 604-620.

Leone, A.J., 2007. Factors related to internal control disclosure: a discussion of Ashbaugh, Collins, and Kinney (2007) and Doyle, Ge, and McVay (2007). Journal of Accounting and Economics 44, 224-237.

Li, C., Wang, Q., 2006. SOX 404 Assessments and Financial Reporting Errors. Working Paper. University of Pittsburgh.

Low, A., 2009. Managerial risk-taking behavior and equity-based compensation. Journal of Financial Economics 92, 470-490.

Lublin, J.S., 2010. Law sharpens 'clawback' rules for improper pay. The Wall Street Journal, June 30.

Masli, A., Peters, G., Richardson, V., Sanchez, J., 2010. Examining the potential benefits of internal control monitoring technology. The Accounting Review 85, 1001-1034.

Morgenson, G., 2008. Pay it back if you didn't earn it. The New York Times, June 8.

Morgenson, G., 2011. Clawbacks without claws. The New York Times, September 10.

Palmrose, Z., Richardson, V.J., Scholz, S., 2004. Determinants of market reactions to restatement announcements. Journal of Accounting and Economics 37, 59-89.

Phillips, F., 1999. Auditor attention to and judgments of aggressive financial reporting. Journal of Accounting Research 37, 167-189.

Plumlee, M., Yohn, T., 2009. An Analysis of the Underlying Causes Attributed to Restatements. Working Paper. University of Utah.

Ross, S.A., 1977. The determination of financial structure: the incentive signaling approach. The Bell Journal of Economics 8, 23-40.

Salehi, N.H., Marino, E.A., 2008. Section 304 of SOX: New tool for disgorgement? New York Law Journal, 239.

Securities and Exchange Commission, 2009. SEC seeks return of \$4 million in bonuses and stock sale profits from former CEO of CSK Auto Corp. 〈http:// www.sec.gov/news/press/2009/2009-167.htm >.

Schwartz, K., Soo, B., 1996. The association between auditor changes and reporting lags. Contemporary Accounting Research 13, 357-370.

Simunic, D.A., 1980. The pricing of audit services: Theory and evidence. Journal of Accounting Research 22, 161-190.

Simunic, D.A., Stein, M.T., 1996. The impact of litigation risk on audit pricing: a review of the economics and the evidence. Auditing: A Journal of Practice \& Theory $15,119-134$.

Spence, M., 1973. Job market signaling. Quarterly Journal of Economics 87, 354-374.

Turner, L., Weirich, T., 2006. A closer look at financial restatements: analyzing the reasons behind the trend. The CPA Journal December, 13-23.

U.S. Department of the Treasury, 2009. Treasury announces new restrictions on executive compensation. Press Release, February 4.

Weiss, T., 2009. Clawbacks are in place and ineffective. Forbes.com, October 29.

Whisenant, S., Sankaragumswamy, S., Raghunandan, K., 2003. Evidence on the joint determination of audit and non-audit fees. Journal of Accounting Research 41, 721-744.

Wilson, W., 2008. An empirical analysis of the decline in information content of earnings following restatements. The Accounting Review 83, 519-548.

Zhang, Y., Zhou, J., Zhou, N., 2007. Audit committee quality, auditor independence, and internal control weaknesses. Journal of Accounting and Public Policy 26, 300-327.

Lilian H. Chan

The University of Hong Kong, Hong Kong

Kevin C.W. Chen*, Tai-Yuan Chen

Hong Kong University of Science and Technology, Kowloon, Hong Kong E-mail address: acchen@ust.hk (K.C.W. Chen)

Yangxin Yu

The Australian National University, Australia

\footnotetext{
* Correspondence to: School of Business and Management, Hong Kong University of Science and Technology, Clearwater Bay, Kowloon, Hong Kong.
} Tel.: +852 23587585 . 